\begin{tabular}{c} 
Brazilian Journal \\
of Chemical \\
Engineering \\
\hline
\end{tabular}

ISSN 0104-6632

Printed in Brazil

www.abeq.org.br/bjche

Vol. 27, No. 04, pp. 531 - 537, October - December, 2010

\title{
STATISTICAL EVALUATION OF MATURE LANDFILL LEACHATE TREATMENT BY HOMOGENEOUS CATALYTIC OZONATION
}

\author{
A. L. C. Peixoto ${ }^{*}$ and H. J. Izário Filho \\ Department of Chemical Engineering, Engineering School of Lorena (EEL), \\ Phone: + (55) (12) 3159-5076, University of São Paulo (USP), \\ Estrada Municipal do Campinho s $/ \mathrm{n}^{\circ}$, Bairro do Campinho, Lorena - SP, Brazil. \\ E-mail: alcpeixoto@gmail.com
}

(Submitted: September 23, 2009 ; Revised: May 13, 2010 ; Accepted: May 18, 2010)

\begin{abstract}
This study presents the results of a mature landfill leachate treated by a homogeneous catalytic ozonation process with ions $\mathrm{Fe}^{2+}$ and $\mathrm{Fe}^{3+}$ at acidic $\mathrm{pH}$. Quality assessments were performed using Taguchi's method ( $\mathrm{L}_{8}$ design). Strong synergism was observed statistically between molecular ozone and ferric ions, pointing to their catalytic effect on ${ }^{\bullet} \mathrm{OH}$ generation. The achievement of better organic matter depollution rates requires an ozone flow of $5 \mathrm{~L} \mathrm{~h}^{-1}\left(590 \mathrm{mg} \mathrm{h}^{-1} \mathrm{O}_{3}\right)$ and a ferric ion concentration of $5 \mathrm{mg} \mathrm{L}^{-1}$.

Keywords: Taguchi orthogonal arrays; Homogeneous catalytic ozonation; Metal ions; Mature leachate.
\end{abstract}

\section{INTRODUCTION}

Several techniques have been used to achieve a satisfactory removal of refractory pollutants from landfills leachates (USEPA, 1998). Due to cost and effectiveness results, biological processes are the most commonly used methods to remove the organic pollutant load from leachates. These methods employ microorganisms to degrade the organic material in municipal landfill leachate (HE et al, 2006). Biological processes are effective for the treatment of young leachate (Chen; Sun; Chung, 2008), which contains a high concentration of volatile fatty acids (VFA). With molecular weights of less than $120 \mathrm{Da}$, VFAs such as acetic acid, butyric acid and propionic acid (Kang et al., 2002) are biodegradable organic matter. Methanogenic bacteria degrade the volatile compounds as the age of the landfill increases. As a result, the $\mathrm{pH}$ rises to higher than 7 and some organic compounds that are present in the leachate are no longer readily degradable. During the methanogenic phase, due to the increase of methanogenic bacteria, the anaerobic degradation process is predominant for 20 to 25 years (Kurniawan; Lo; Chan, 2006). This results in a stabilized leachate generation with high molecular weight refractory compounds such as humic and fulvic acids, characterized by a high concentration of ammonia $\left(3,000-5,000 \mathrm{mg} \mathrm{L}^{-1}\right)$, a moderate value of $\operatorname{COD}\left(5,000-20,000 \mathrm{mg} \mathrm{L}^{-1}\right)$ and a low $\mathrm{BOD} / \mathrm{COD}$ ratio of less than 0.1 (Kurniawan; Lo; Chan, 2006). Therefore, recalcitrant leachate is not effectively treated by biological processes such as activated sludge, anaerobic lagoons, anaerobic filters and wetlands.

Advanced oxidation processes (AOP) are considered promising technologies for mature leachate treatment due to the powerful increase of the biodegradability of recalcitrant wastewater (Freire et al., 2000; Pacheco and Peralta-Zamora, 2004; Morais and Zamora, 2005; Kurniawan; Lo; Chan, 2006). Regarding the irradiation-based processes (photo-Fenton, $\mathrm{H}_{2} \mathrm{O}_{2} / \mathrm{UV}, \mathrm{O}_{3} / \mathrm{UV}$ etc.), leachate wastewater presents a serious

*To whom correspondence should be addressed 
inconvenience, which is the reduction of the photoprocess efficiency due to the high concentration of humic and fulvic acids, which absorb radiation in the visible/ultraviolet. (Pacheco and Peralta-Zamora, 2004).

Homogeneous catalytic ozonation has high potential among other advanced technologies applied to depollute recalcitrant effluents. It is capable of attaining elevated rates of organic matter mineralization, mainly at acidic $\mathrm{pH}$, that are not observed in the conventional process of ozonation due to the formation of refractory compounds. In addition, scavengers of the hydroxyl radical do not interfere in the catalytic process of ozonation and will eventually be oxidized by ozone. As a result, catalytic processes exhibit higher efficiency for the removal of organic load and reduced consumption of ozone. However, some considerations should be taken into account related to the catalytic process, such as: a) limited solubility of the catalyst in the reaction environment; $b$ ) the difficulty of reusing the catalysts employed in the process; c) the necessity to employ - after the catalytic ozonation process metal ion removal techniques (such as adsorption) due to potential toxic, adverse and unwanted effects (Assalin; Durán, 2007).

The aim of this work is to degrade the organic compounds of a recalcitrant leachate from the old landfill of the city of Guaratinguetá, Vale do Paraiba, São Paulo, exclusively by the homogeneous catalytic ozonation method with ferric and ferrous ions, treating the leachate in natura, extending our previous work (Peixoto et. al., 2009). For this evaluation, the quality tools of Taguchi's $\mathrm{L}_{8}$ orthogonal array were used.

\section{MATERIALS AND METHODS}

\section{Sample and Preservation}

Two hundred liters of leachate from the landfill site (30 years old) of Guaratinguetá city (State of São Paulo, Brazil) were collected to perform the study of the effluent treatment by the catalytic ozonation process. Immediately after collection, the effluent was conditioned at $4^{\circ} \mathrm{C}$ to minimize alterations of its physical-chemical properties (APHA, 1999).

\section{Determination of the Analytical Parameter COD}

All analytical determinations were performed according to the Standard Methods of Examination of Water and Wastewater (APHA, 1999). COD determinations were performed in a Hach tube, followed by spectrophotometric determination (Fentom 600 spectrophotomer) at $620 \mathrm{~nm}$. Analytical determinations of COD of the treated leachate samples were carried out immediately after the conclusion of each experiment of catalytic ozonation. There was no sample filtration prior to the respective leachate digestion in the closed Hach tube (Peixoto et al., 2008; Peixoto et al., 2009).

\section{Rate of Production of Ozone}

The ozone used in experimental treatments of leachate was produced by the conversion of $\mathrm{O}_{2}$ to $\mathrm{O}_{3}$ through the use of an Auje Inc. Model MV 01 equipment. The generation of ozone was by the electric discharge method with dielectric-barriers (Corona effect) with the following operational characteristics: nominal tension of $220 \mathrm{~V}$, maximum potential of $60 \mathrm{~W}$ and working pressure of 2 bars. From the ozonizer stage until the final experimental treatment of the landfill leachate, an ozone-feeding generator was used with oxygen (Aga) of a nominal purity of $99.99 \%$ (Peixoto et. al., 2009).

\section{Definition of the Reaction Time to Degrade Leachate by Ozonation}

To define the total reaction time of mature leachate treatment by ozonation, the in natura wastewater ozonation was performed to obtain the percentage removal profile of COD. Sample aliquots $(1.0 \mathrm{~mL})$ were taken every 30 min over a $6 \mathrm{~h}$ experiment. The leachate was treated as collected in the municipal landfill, with no further pretreatment, such as filtration. The following experimental conditions were used, according to a previous study (Peixoto et al., 2009): ozone flow rate at $5 \mathrm{~L} \mathrm{~h}^{-1}$, iron concentration equal to $20 \mathrm{mg} \mathrm{L}^{-1}, \mathrm{Zn}^{2+}$ concentration equal to $2.5 \mathrm{mg} \mathrm{L}^{-1}, \mathrm{Mn}^{2+}$ concentration equal to 0.5 $\mathrm{mg} \mathrm{L}^{-1}, \mathrm{Ni}^{2+}$ concentration equal to $1.0 \mathrm{mg} \mathrm{L}^{-1}, \mathrm{Cr}^{3+}$ concentration equal to $5.0 \mathrm{mg} \mathrm{L}^{-1}$, and $\mathrm{pH}$ equal to 5.0. Moreover, the temporal control of leachate degradation (\% COD removal) was performed in some of the experiments of Taguchi's $\mathrm{L}_{8}$ design in order to confirm the results obtained in the preliminary experiment.

\section{Treatment of in Natura Landfill Leachate by Catalytic Ozonation in a Semibatch Reactor}

All leachate treatment stages were conducted in a reactor consisting of a borosilicate glass sheath, with water recirculation at a constant temperature of $25^{\circ} \mathrm{C}$. 
Ozone feeding into the wastewater was performed continuously at the reactor bottom (Peixoto et al., 2009). In all leachate treatment experiments by catalytic ozonation, $900 \mathrm{~mL}$ of effluent was used as collected at the landfill site. The two process parameters, ozone flow rate and reaction $\mathrm{pH}$, were both kept constant during all the reaction time $(4 \mathrm{~h})$.

Taguchi's $\mathrm{L}_{8}$ orthogonal array (Table 1) and its associated quality tools were applied to the process of in natura wastewater treatment. The following factors were evaluated: ozone flow rate (factor $\mathrm{A}$ ), $\mathrm{Fe}^{2+}$ concentration (factor $\mathrm{B}$ ), $\mathrm{Fe}^{3+}$ concentration (factor $\mathrm{C}$ ) and reaction $\mathrm{pH}$ (factor $\mathrm{D}$ ). Table 1 shows the values of each level chosen for the statistical evaluation of leachate treatment. Real experimental duplicates of the fractional factorial design were carried out to obtain the process error involved.

Table 1: Taguchi's $L_{8}$ orthogonal array at 2 levels.

\begin{tabular}{|c|c|c|c|c|}
\hline \multirow[b]{2}{*}{$\mathbf{N}$} & \multicolumn{4}{|c|}{ Experimental Factors } \\
\hline & $\begin{array}{c}\mathrm{O}_{3} \\
\left(\mathrm{~L} \mathrm{~h}^{-1}\right)\end{array}$ & $\begin{array}{c}\mathrm{Fe}^{2+} \\
\left(\mathrm{mg} \mathrm{L}^{-1}\right)\end{array}$ & $\begin{array}{c}\mathrm{Fe}^{3+} \\
\left(\mathrm{mg} \mathrm{L}^{-1}\right)\end{array}$ & pH \\
\hline 1 & $3.0^{\mathrm{A}}$ & 5.0 & 5.0 & 2.0 \\
\hline 2 & 3.0 & 5.0 & 10.0 & 5.0 \\
\hline 3 & $5.0^{\mathrm{B}}$ & 10.0 & 5.0 & 2.0 \\
\hline 4 & 5.0 & 10.0 & 10.0 & 5.0 \\
\hline 5 & 3.0 & 10.0 & 5.0 & 5.0 \\
\hline 6 & 3.0 & 10.0 & 10.0 & 2.0 \\
\hline 7 & 5.0 & 5.0 & 5.0 & 5.0 \\
\hline 8 & 5.0 & 5.0 & 10.0 & 2.0 \\
\hline
\end{tabular}

A: mass feeding of $(265 \pm 20) \mathrm{mg} \mathrm{h}^{-1} \mathrm{O}_{3}$

B: mass feeding of $(600 \pm 30) \mathrm{mg} \mathrm{h}^{-1} \mathrm{O}_{3}$

\section{RESULTS AND DISCUSSION}

In a previous work, Peixoto et. al. (2009) developed an exploratory study of mature municipal landfill leachate treatment by homogeneous catalytic ozonation $\left(\mathrm{Fe}^{3+}, \mathrm{Zn}^{2+}, \mathrm{Mn}^{2+}, \mathrm{Ni}^{2+}\right.$ and $\mathrm{Cr}^{3+}$ catalysts), evaluating the percentage COD removal by Taguchi's $\mathrm{L}_{16}$ orthogonal array. In the present work, unlike the previous one, only iron ions $\left(\mathrm{Fe}^{2+}\right.$ and $\left.\mathrm{Fe}^{3+}\right)$ are used as catalysts in the ozonation process because they are less toxic (Brazil, 2009). An acidic range of $\mathrm{pH}$ was also used (Table 1). The acidic $\mathrm{pH}$ results in higher metal ion solubility (Azher et al., 2008).

A preliminary experimental (Figure 1) employing the $\mathrm{L}_{8}$ planning was carried out to determine the total time of chemical reaction required for ozonation of mature leachate. In our previous work (Peixoto et. al., 2009), a total of $30 \mathrm{~min}$ of reaction was used since it was an exploratory study to determine the significant factors involved into the mineralization of municipal landfill leachate and their best configuration.

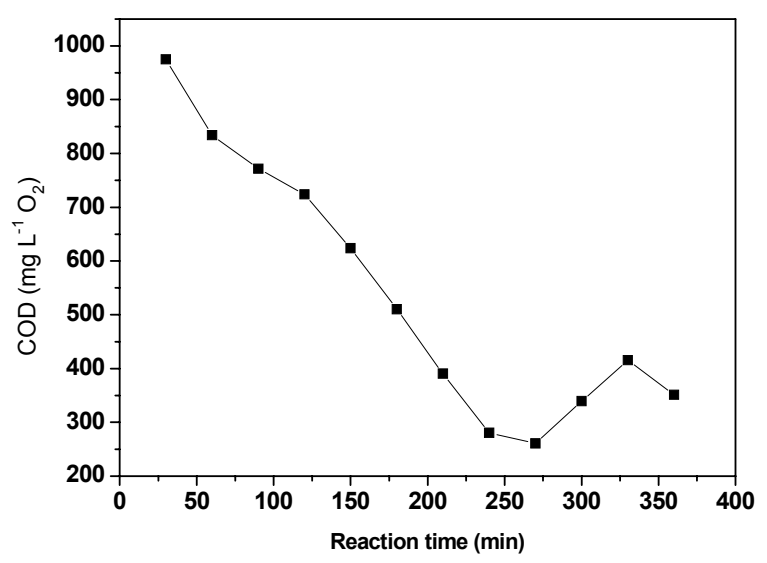

Figure 1: Preliminary experiment to determine the total time of homogeneous catalytic ozonation (inlet flow rate of $5 \mathrm{~L} \mathrm{~h}^{-1}$, inlet ozone mass rate of $600 \mathrm{mg} \mathrm{h}^{-1}$ ).

According to the experimental data in Figure 1, there is a linear trend in the degradation of organic matter of the mature leachate, with a minimum value of chemical oxygen demand $\left(260 \mathrm{mg} \mathrm{L}^{-1} \mathrm{O}_{2}\right)$ by approximately $4 \mathrm{~h}$ of catalytic ozonation. In order to standardize the chemical reaction time for all experiments of the fractional factorial design, they were performed using $4 \mathrm{~h}$ of chemical reaction, which corresponds to a maximum ozone feed of approximately $2.36 \mathrm{~g}$. As described in the Standard Methods of Examination of Water and Wastewater (APHA, 1999), the chemical oxygen demand method is capable of oxidizing most organic compounds. However, some compounds (e.g., pyridine) resist chemical oxidation. As shown in Figure 1, a minor COD increment is verified for reaction times of 270$330 \mathrm{~min}$, which might reflect resistance to oxidation of a small fraction of the organic content present in the wastewater before a reaction time of $270 \mathrm{~min}$. After 330-min of ozonation reaction, residual compounds in the treated effluent become more readily oxidizable and thus COD depletion prevails once more.

Table 2 shows experimental results for COD (minimum values, maximum values and respective standard deviation), besides the mean percentage reduction of COD, obtained in the leachate treatment by catalytic ozonation according to Taguchi's $\mathrm{L}_{8}$ design. Experimental data is distributed in two different sets, which represent real duplicates of each experimental condition, with a total result of 16 experiments. 
According to Table 2, a minimum reduction of COD was observed for experimental condition 1 (factors A, B, C, and D at the low level), with a reduction of $29.4 \%$, and maximum removal of COD of $48 \%$ for experiment 5 (factors $\mathrm{A}$ and $\mathrm{B}$ at the high level; factors $\mathrm{C}$ and $\mathrm{D}$ at the low level) of Taguchi's $\mathrm{L}_{8}$ design. Figure 2 shows the residuals analysis of the results presented in Table 2.

Figure 2 shows that the residuals for leachate treatment experiments performed according to
Taguchi's $\mathrm{L}_{8}$ have a normal distribution centered around zero. This normal distribution of residuals points to a good quality of the experimental data in Table 2, with no outliers and/or gross errors. According to Montgomery (2001), examination of the residuals should be an automatic part of any analysis of variance, guaranteeing the reliability of experimental results. Table 3 shows the ANOVA of the factors involved in the leachate treatment regarding the response variable (Table 2).

Table 2: Minimum, maximum and mean results of leachate COD $\left(\mathrm{mg} \mathrm{L}^{-1}\right)$ after 4 hour homogeneous catalytic ozonation experiments, with respective values of the standard deviation (SD) and number (N) of analytical replicates.

\begin{tabular}{|c|c|c|c|c|c|c|c|c|c|c|c|c|}
\hline & \multicolumn{9}{|c|}{ First Set } & \multicolumn{4}{c|}{ Second Set } \\
\hline $\begin{array}{c}\text { Taguchi's } \\
\text { experiment } \\
\text { run }\end{array}$ & Minimum & Maximum & Mean & SD & N & $\begin{array}{c}\text { COD } \\
\text { Removal } \\
(\%)\end{array}$ & Minimum & Maximum & Mean & SD & $\begin{array}{c}\text { COD } \\
\text { Removal } \\
\text { (\%) }\end{array}$ \\
\hline 1 & 676 & 793 & 723 & 50 & 6 & 29 & 641 & 759 & 708 & 49 & 5 & 30 \\
2 & 613 & 780 & 680 & 63 & 7 & 33 & 530 & 766 & 623 & 80 & 7 & 38 \\
3 & 641 & 731 & 688 & 32 & 7 & 32 & 655 & 745 & 701 & 45 & 3 & 31 \\
4 & 502 & 703 & 574 & 83 & 5 & 43 & 537 & 599 & 576 & 34 & 3 & 43 \\
5 & 482 & 565 & 515 & 69 & 7 & 49 & 516 & 572 & 544 & 39 & 2 & 46 \\
6 & 655 & 745 & 701 & 45 & 3 & 31 & 634 & 800 & 695 & 63 & 5 & 31 \\
7 & 440 & 787 & 574 & 109 & 7 & 43 & 495 & 606 & 547 & 40 & 7 & 46 \\
8 & 627 & 904 & 703 & 95 & 7 & 31 & 676 & 773 & 705 & 39 & 5 & 30 \\
\hline
\end{tabular}

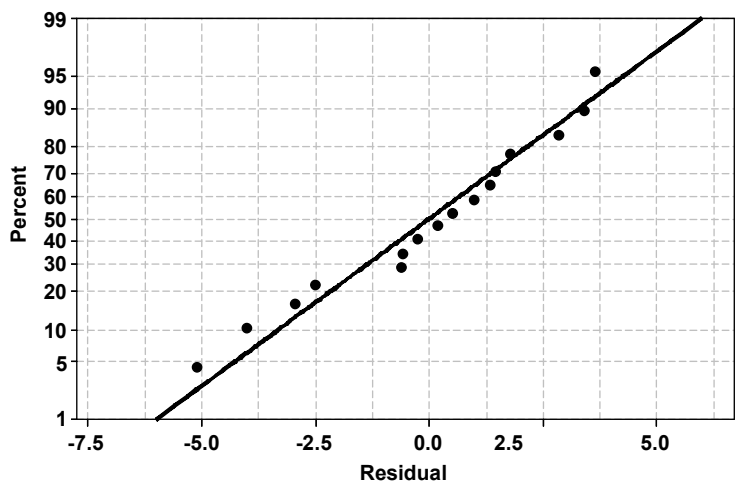

Figure 2: Normal probability plot of residuals for experimental data from Taguchi’s $\mathrm{L}_{8}$ design.

Table 3: Analyses of Variance (ANOVA) obtained by using mean results of percentage COD reduction from the $L_{8}$ experimental design.

\begin{tabular}{|c|c|c|r|r|r|}
\hline Source & Degrees of Freedom & Sum of Squares & Mean Squares & \multicolumn{1}{c|}{ F } & P \\
\hline A & 1 & 50.72 & 50.72 & 16.06 & 0.004 \\
B & 1 & 8.85 & 8.85 & 2.80 & 0.133 \\
C & 1 & 40.80 & 40.80 & 0.91 & 0.007 \\
D & 1 & 2.24 & 4.24 & 13.78 & 0.424 \\
AB & 1 & 53.53 & 596.81 & 188.91 & 0.006 \\
AC & 1 & 15.81 & 15.48 & 4.90 & 0.058 \\
AD & 1 & 25.27 & 40.75 & & \\
Error & 8 & 783.70 & & & \\
Total & 15 & &
\end{tabular}


As shown in Table 3, the factors ozone flow rate (factor $\mathrm{A}$ ), $\mathrm{Fe}^{2+}$ concentration (factor $\mathrm{B}$ ) and $\mathrm{Fe}^{3+}$ concentration (factor $\mathrm{C}$ ) are statistically significant, with confidence degrees of $99.6 \%, 86.7 \%$ and $98.5 \%$, respectively. It is also observed that the $\mathrm{pH}$ exerts no influence on the response due to the low value presented by the $\mathrm{F}$ test $(\mathrm{F}=0.71)$. Comparing the information of the F test, it can be observed that ozone is 6 times more significant than ferrous ion and 1.2 times more significant than ferric ion. The factor $\mathrm{Fe}^{3+}$ concentration (C) is approximately 5 times more significant in the leachate degradation than the factor $\mathrm{Fe}^{2+}$ concentration (B). An antagonist effect is observed through ANOVA (Table 3) between factors $\mathrm{A}$ and $\mathrm{B}$ (interaction $\mathrm{AB}$ ) and factors $\mathrm{A}$ and $\mathrm{D}$ (interaction $\mathrm{AD}$ ), the F-test for these interactions (13.78 for $\mathrm{AB}$ and 4.90 for $\mathrm{AD}$ ) being lower than the value presented by the main effect of A $(F=16.06)$.

Among different methods used for ozone generation, the dielectric barriers method (Corona effect) provides the highest conversion rates of $\mathrm{O}_{2}$ to $\mathrm{O}_{3}$, attaining a conversion of up to $14 \%(\mathrm{~m} / \mathrm{m})$ with air feed or pure oxygen in the ozone generator (Almeida et al., 2004). The antagonism presented by $\mathrm{AB}$ may reflect the constant oxygen stream in the interior of the liquid effluent, resulting in oxidation of $\mathrm{Fe}^{2+}$. Equation 1 shows the stoichiometric relationship of soluble iron oxidation in the presence of dissolved oxygen (Azher et al., 2008), demonstrating that $1 \mathrm{mg}$ of oxygen oxides approximately $7 \mathrm{mg}$ of ferrous ion, generating sludge of ferric ion, according to Equation 2.

$$
\begin{aligned}
& 4 \mathrm{Fe}^{2+}+\mathrm{O}_{2}+4 \mathrm{H}_{3} \mathrm{O}^{+} \rightarrow 4 \mathrm{Fe}^{3+}+6 \mathrm{H}_{2} \mathrm{O} \\
& 4 \mathrm{Fe}^{3+}+12 \mathrm{OH}^{-} \rightarrow 4 \mathrm{Fe}(\mathrm{OH})_{3}
\end{aligned}
$$

Taguchi's $\mathrm{L}_{8}$ design was conducted at an acidic reaction $\mathrm{pH}$, thus limiting the in situ generation of hydroxyl free radicals by the $\mathrm{O}_{3} / \mathrm{OH}^{-}$technique (Equation 3 to 6). This fact justifies the antagonistic effect of interaction between ozone and the reaction $\mathrm{pH}$ (interaction $\mathrm{AD}$ ), as shown in Equations 3 and 4.

$$
\begin{aligned}
& \mathrm{O}_{3}+\mathrm{OH}^{-} \rightarrow \mathrm{O}_{2}^{\bullet-}+\mathrm{HO}_{2}^{\bullet} \\
& \mathrm{HO}_{2}^{\bullet} \leftrightarrow \mathrm{O}_{2}^{-}+\mathrm{H}^{+} \\
& \mathrm{O}_{3}+\mathrm{O}_{2}^{\bullet-} \rightarrow \mathrm{O}_{3}^{\bullet-}+\mathrm{O}_{2}
\end{aligned}
$$

$$
\mathrm{O}_{3}^{\bullet-}+\mathrm{H}^{+} \leftrightarrow \mathrm{HO}_{3}^{\bullet} \quad \mathrm{pH}<8
$$

Second-order interactions between the factors ozone flow rate (A) and $\mathrm{Fe}^{3+}$ concentration (C) show clear synergism; the $\mathrm{F}$ value of the interaction $\mathrm{AC}$ is approximately 12 times bigger than the $\mathrm{F}$ value presented by factor A and approximately 15 times bigger than the $\mathrm{F}$ value presented by factor $\mathrm{C}$. The strong synergistic response of $\mathrm{AC}$ indicates a catalytic action of $\mathrm{Fe}^{3+}$ on ${ }^{\bullet} \mathrm{OH}$ generation from ozone $\left(\mathrm{O}_{3}\right)$.

Figure 3 shows the main effect of $\mathrm{L}_{8}$ orthogonal array factors with respect to the response variable (\% COD reduction).

Figure 3 outlines the best experimental configuration achieved according to the main effects of the factors ozone flow rate (A), $\mathrm{Fe}^{2+}$ concentration (B), $\mathrm{Fe}^{3+}$ concentration (C) and reaction $\mathrm{pH}(\mathrm{D})$. Aiming at increasing the response variable value, thus maximizing the value of percentage COD reduction, the following configuration should be preferred: high levels for factors $\mathrm{A}$ and $\mathrm{B}$ and low levels for factors $\mathrm{C}$ and $\mathrm{D}$. However, assuming that there is a considerable synergism between $\mathrm{O}_{3}$ and $\mathrm{Fe}^{3+}$ with this effect being more significant than the effect of isolated factors according to ANOVA (Table 3), better experimental conditions are ozone at a high level (flow rate at $5 \mathrm{~L} \mathrm{~h}^{-1}$ ) and $\mathrm{Fe}^{3+}$ concentration at the low level $\left(5 \mathrm{mg} \mathrm{L}^{-1}\right)$. This behavior can be explained by ozonation mechanism, favoring the kinetic formation of hydroxyl radicals (Mahmoud; Freire, 2007):

(i) under acidic conditions $(\mathrm{pH} \leq 4)$, the direct mechanism or ozonolysis reaction, (Criegee mechanism) prevails;

(ii) at higher concentrations of ferrous ions at acidic $\mathrm{pH}$ (Equations 8 to 10), a competition between the species of iron and the radical ${ }^{\circ} \mathrm{OH}$ occurs, diminishing the efficiency of the oxidative process.

$$
\begin{aligned}
& \mathrm{Fe}^{2+}+\mathrm{O}_{3} \rightarrow \mathrm{Fe}^{3+}+\mathrm{O}_{3}^{\bullet-} \\
& \mathrm{O}_{3}^{\bullet-}+\mathrm{H}^{+} \leftrightarrow \mathrm{HO}_{3}^{\bullet} \rightarrow \bullet \mathrm{OH}+\mathrm{O}_{2} \\
& \mathrm{Fe}^{2+}+{ }^{\bullet} \mathrm{OH} \rightarrow \mathrm{Fe}^{3+}+\mathrm{OH}^{-}
\end{aligned}
$$

Figure 4 shows the main effect with respect to the signal-to-noise ratio of the factors used in the leachate treatment by homogeneous catalytic ozonation. 


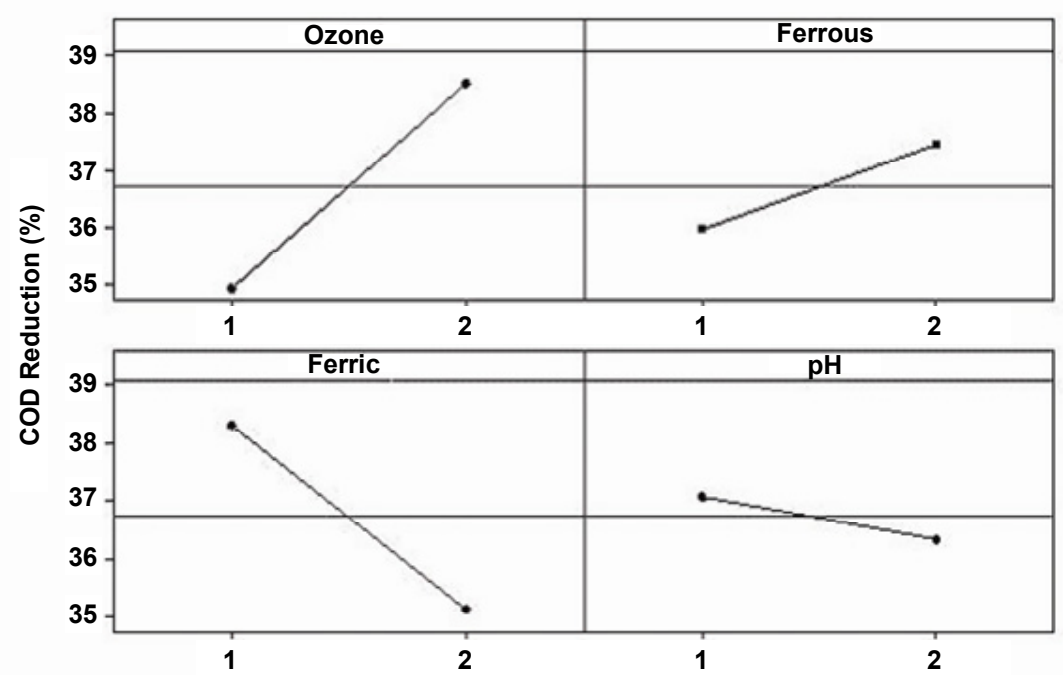

Figure 3: Main effects plot of the factors used in leachate treatment by homogeneous catalytic ozonation ( $\mathrm{L}_{8}$ planning of experiment).

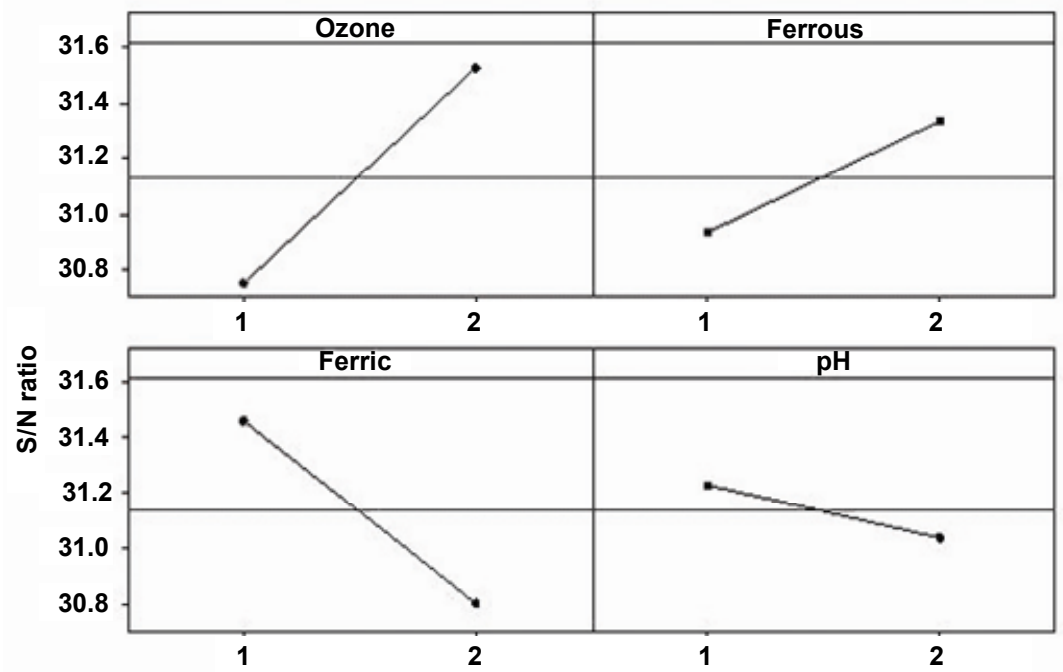

Figure 4: Signal-to-noise ratio plot for the factors used in leachate treatment by homogenous catalytic ozonation (condition "higher is better").

As stated by Maghsoodloo et al. (2004), an S/N response graph helps to identify the factors that control the process variation. Maximizing the $\mathrm{S} / \mathrm{N}$ ratios is equivalent to minimizing the variance (and thus maximizes simultaneously the mean). A better configuration of factors is obtained by the following parameter adjustment: high levels for factors $\mathrm{A}$ and $\mathrm{B}$ and low levels for factors $\mathrm{C}$ and $\mathrm{D}$, considering the 'larger is better' condition. This adjustment is identical to the one obtained by analysis of the main factors with respect to the response variable (Figure 3). The same way, as previously discussed, close attention must be paid to the level adjustment of the factors $\mathrm{O}_{3}$ and $\mathrm{Fe}^{3+}$, in which both factors present a strong synergism $\left(\mathrm{F}\right.$-test ${ }_{\mathrm{AC}}>>\mathrm{F}$-test $\left.\mathrm{A}_{\mathrm{A}}\right)$. The results from $\mathrm{S} / \mathrm{N}$ ratio adjustment confirm the best experimental condition achieved by the main effect study (Figure 3), which justifies the focus on adjustment of ozone at a high level (flow rate at $5 \mathrm{~L} \mathrm{~h}^{-1}$ ) and $\mathrm{Fe}^{3+}$ concentration at the low level $\left(5 \mathrm{mg} \mathrm{L}^{-1}\right)$. 


\section{CONCLUSIONS}

Technical viability was shown for mature landfill leachate treatment through the homogeneous catalytic ozonation technique by application of metal ions of low environmental impact (especially $\mathrm{Fe}^{3+}$ ) as catalysts at acidic $\mathrm{pH}$. Taguchi's $\mathrm{L}_{8}$ method provided quality tools to verify the influence of factors involved in the wastewater treatment process, identifying the more influential factors as to be molecular ozone and ferric ion, with strong synergism between them. It is concluded that the best results can be obtained using an ozone flow rate of $5 \mathrm{~L} \mathrm{~h}^{-1}\left(600 \mathrm{mg} \mathrm{h}^{-1} \mathrm{O}_{3}\right)$ and a concentration of ferric ion equal to $5 \mathrm{mg} \mathrm{L}^{-1}$. The factors $\mathrm{Fe}^{2+}$ concentration and $\mathrm{pH}$ were proven to be less significant in the leachate treatment by the experimental methodology, in spite of being important parameters for the degradation by ozonation, according to the mechanisms previously discussed.

\section{REFERENCES}

APHA, American Public Health Association, Standard Methods for Examination of Water and Wastewater (APHA, AWWA). 20th ed., New York, WPCF (1999).

Assalin, M. R., Durán, N., Novas tendências para aplicação de ozônio no tratamento de resíduos: ozonização catalítica. Revista Analytica, (SP). n. 26, 76 (2007).

Azher, N. E., Gourich, B., Vial, C., Soulami, M. B., Ziyad, M., Study of ferrous iron oxidation in Morocco drinking water in an airlift reactor. Chemical Engineering and Processing, 47, 1877 (2008).

Brazil, Ministry of Environment. Environmental National Council, CONAMA. Resolution N. 357, March 17, 2005. Available at www.mma.gov.br/ port/conama/res/res05/res35705.pdf. Access in September (2009).

Freire, R. S., Pelegrini, R., Kubota, L. T., Duran, N., Peralta-Zamora, P., Novas tendências para o tratamento de resíduos industriais contendo espécies organocloradas. Química Nova, v. 23, n. 4, 504 (2000).

He, J., Xue, J., Shao, L., Li, G., Lee, D., Dissolved organic matter (DOM) in recycled leachate of bioreactor landfill. Water Research, v. 40, 1465 (2006).

Kang, K., Shin, H. S., Park, H., Characterization of humic substances present in landfill leachates with different landfill ages and its implications. Water Research, v. 36, 4023 (2002).

Kurniawan, T. A., Lo, W., Chan, G. Y. S., Degradation of recalcitrant compounds from stabilized landfill leachate using a combination of ozone-GAC adsorption treatment. Journal of Hazardous Materials, v. B137, 443 (2006).

Maghsoodloo, S., Ozdemir, G., Jordan, V., Huang, C., Strengths and Limitations of Taguchi's Contributions to Quality. Manufacturing, and Process Engineering, Journal of Manufacturing Systems, 23 (2), 73 (2004).

Mahmoud, A. and Freire, R. S., New methods for enhancing ozone efficiency on contaminated water treatment, Quimica Nova, 30, No. 1, 198 (2007).

Montgomery, D. C., Design and Analysis of Experiments, 5th ed., New York, John Wiley \& Sons (2001).

Morais, J. L., Zamora, P. P., Use of advanced oxidation processes to improve the biodegradability of mature landfill leachates. Journal of Hazardous Materials, v. B123, 181 (2005).

Pacheco, J. R., Peralta-Zamora, P. G., Integração de processos físico-químicos e oxidativos avançados para remediação de percolado de aterro sanitário (chorume). Engenharia Sanitária e Ambiental, v. 9, n. 4, 306 (2004).

Peixoto, A. L. C., Brito, R. A., Salazar, R. F. S., Guimarães, O. L. C., Izário Filho, H. J., Prediction of Chemical Oxygen Demand in natura landfill leachate doped with Fenton's reagent, using mathematical empiricism model obtained by full factorial design. Quimica Nova, 31, 1641 (2008).

Peixoto, A. L. C., Silva, M. B., Izário Filho, H. J., Leachate treatment process at a municipal stabilized landfill by catalytic ozonation: an exploratory study from Taguchi orthogonal array. Brazilian Journal of Chemical Engineering, 26, (3), 481 (2009).

United States Environmental Protection Agency (USEPA), Advanced Photochemical Oxidation Processes. EPA/625/R-98/004, EPA: Washington (1998). 